\title{
Response of local potato cultivars to late blight disease (Phytophthora infestans (mont.) De bary) under field and laboratory conditions at Pakhribas, Dhankuta, Nepal
}

\begin{abstract}
Seven local potato cultivars along with two checks (Kufri Jyoti and Janakdev) were evaluated for their resistance against late blight caused by Phytophthora infestans in 2016 at Pakhribas, Dhankuta, Nepal under field and laboratory conditions. Field experiment was conducted under natural epiphytotic conditions. Laboratory experiments included detached leaf and tuber slice assays under artificially inoculated conditions. In the field, Lumle Kalo and Janakdev showed resistant reaction while cultivars Hale, Rato, Lumle Seto, Kalo and Seto-moderately resistant, and Phulsusceptible to late blight. In detached leaf assay, Janakdev showed highly resistant reaction; Kalo-resistant; Lumle Kalo and Hale-moderately resistant; and Lumle Seto, Rato, Seto and Phul-susceptible reactions. In tuber slice assay, Kalo, Lumle Kalo, Phul and Rato showed resistant reaction; Janakdev and Seto-moderately resistant; and Hale and Lumle Seto-susceptible. The check cultivar Kufri Jyoti gave highly susceptible reactions in all the experiments. Susceptibility levels measured in the detached leaf assay was highly correlated $(\mathrm{r}=0.70)$ with converted field scale values, although the correlation was lower for the tuber slice assay $(\mathrm{r}=0.58)$. Low correlation in the tuber assay may have also reflected genetic systems and/or structural differences as foliage and tuber blight resistance are not always correlated. Lumle Kalo can be utilized as source of resistance against late blight for breeding and general cultivation by farmers of Pakhribas and similar conditions.
\end{abstract}

Keywords: assay, correlation, isolate, resistant, screening, susceptible

\section{Introduction}

Late blight, caused by the Oomycete pathogen Phytophthora infestans (Mont.) de Bary, is one of the most important, ${ }^{1}$ and major yield-limiting diseases in all potato-growing areas of the world, ${ }^{2,3}$ costing over $€ 12$ billion in crop losses and control measures. ${ }^{4}$ The disease was first reported in Nepal between 1883 and $1897 .{ }^{5}$ It appears in epidemic proportion in the high hills every year but in the plains (Terai) it occurs sporadically. ${ }^{6}$ In the high hills, losses have been encountered more than $75 \%$ and in the Terai losses have been reported $50-90 \%$ in some years. ${ }^{7}$ A nationwide crop failure due to late blight was observed in $1996 .{ }^{8}$ When yield loss due to late blight is estimated to a minimum level of $20 \%$, the national economic loss reaches up to NRs 1.8 billion (USD 25 million) annually. ${ }^{9}$ One of the most effective and efficient ways to control any plant disease is host plant resistance. Potato cultivars resistant to unpredictable climate change and disease are highly demanding. In case of late blight, fungicide treatments for the management are more common but the frequent and haphazard use of fungicide creates for the emergence of new virulent races which may cause havoc in potato cultivation by the breakdown of resistance even in resistant cultivars. There is a tendency of development of resistant fungal races against use of systemic fungicides. ${ }^{10}$ Moreover, host resistance can allow significant reduction in fungicides application while maintaining the yield and quality of the produce. ${ }^{11}$ One way to identify stable resistance in the germplasm lines is to evaluate them temporally (two or more seasons testing at a location) or spatially (several locations) or a combination of these. ${ }^{12}$ The National Potato Research Program (NPRP) of Nepal regularly evaluates potato cultivars in multiple locations for resistance to $P$. infestans in replicated field trials, in
Volume 4 Issue I - 2019

\begin{abstract}
Sundar Shrestha, Hira Kaji Manandhar, Sundar Man Shrestha, Ajaya Karkee

Department of Agriculture and Forestry University, Nepal
\end{abstract}

Correspondence: Sundar Shrestha, Department of Agriculture and Forestry University, Nepal,

Email sundarsansar7I@gmail.com

Received: August 13,2018 | Published: February 22, 2019 which the effect of resistance on the polycyclic development of the disease can be assessed. Resistance can also be evaluated in more convenient and often less expensive monocyclic or oligocyclic green-house or laboratory assays in which one or more epidemic components, such as lesion expansion rate or sporulation, are measured. ${ }^{13}$ Resistance to tuber blight caused by $P$. infestans may or may not, ${ }^{14-16}$ be correlated with foliar resistance. Therefore, it is essential to test breeding lines for susceptibility to P. infestans in both tubers and foliage. ${ }^{17-26}$ The objectives of this study were to determine the incidence and severity of late blight disease in local potato cultivars under field conditions in Pakhribas, Dhankuta and measure their susceptibility to late blight using detached leaf and tuber slice assays.

\section{Methodology}

\section{Experiment I: Evaluation of local potato cultivars against late blight under natural epiphytotic conditions}

The field experiment was conducted at Pakhribas -5 , Dhankuta in 2016. The field research site is situated at 1715 meters above sea level and lies at $27.04581^{\circ} \mathrm{N}$ latitude and $87.29641^{\circ} \mathrm{E}$ longitude and $0.5 \mathrm{~km}$ east of Agricultural Research Station (ARS), Pakhribas, Dhankuta. Seven local cultivars of potato: Seto, Kalo, Rato, Phul, Hale, Lumle Seto and Lumle Kalo were collected from farmers of Sidhuwa-7, Terathum. Two check varieties Janakdev as resistant and Kufri Jyoti as susceptible were obtained from the National Potato Research Program (NPRP), Khumaltar, Lalitpur. The experiment was conducted under natural epiphytotic conditions. Individual plot 
size was $3 \mathrm{~m}^{2}(2.5 \mathrm{mx} 1.2 \mathrm{~m})$. There were 2 rows per plot, $60 \mathrm{~cm}$ apart with plant to plant distance of $25 \mathrm{~cm}$. Each row had 10 plants. Field was surrounded by late blight susceptible variety Kufri Jyoti to exert more disease pressure. Farm yard manure@20ton/ha was applied during land preparation. Plant nutrients in the form of $\mathrm{N}$, $\mathrm{P}_{2} \mathrm{O} 5$ and $\mathrm{K}_{2} \mathrm{O} @ 100: 100: 60 \mathrm{~kg} / \mathrm{ha}$, respectively, through urea, diammonium phosphate and muriate of potash, were applied prior to planting. Sprouted potato seed tubers of approximately similar physiological age were planted at 5-6cm depth. Planting was done on 19th September 2016. Irrigation was given at 30 and 45 days after planting. Six plants were randomly selected ( 3 plants from each row) per plot and tagged for disease scoring. All the field observation data were recorded from the sampled plants.

\section{Experiment 2: Evaluation of local potato cultivars against late blight using detached leaf and tuber slice techniques}

The laboratory works were carried out in the laboratory of ARS, Pakhribas from September 2016 to January 2017. For detached leaf assay, apical leaflets of leaves from the middle part of test potato cultivars at near flowering stage (grown in a screen house) were taken. Prior to inoculation, leaflets were washed and placed abaxial surface-up on glass slides in Petri dishes containing two layers of water-soaked blotting papers. One $50 \mu 1$ drop of inoculums $\left(3 \times 10^{3}\right.$ sporangia $\mathrm{ml}^{-1}$ ) of $P$. infestans was inoculated onto each leaflet using a micropipette. Three leaflets per cultivar were used as sub-samples and inoculated leaflets were incubated at $16 \pm 0.5^{\circ} \mathrm{C}$ with $12 \mathrm{hr}$ light cycle for disease development. On the 7th day after inoculation, the mean diameter of the lesion on each leaflet was measured as described by. ${ }^{17}$ The experiment was repeated twice. For tuber slice assay, three medium-sized, apparently healthy tubers of test cultivars were washed with tap water, soaked in $4 \%$ commercial grade sodium hypochlorite $(\mathrm{NaOCl})$ solution for 30 seconds, rinsed with distilled water three times and air- dried. A 5-mm-thick section from the middle of each tuber was cut and placed in a glass slide in a Petri dish containing two layers of water-soaked blotting papers. Inoculation was done by placing one drop $(50 \mu 1)$ of inoculum with $3 \times 10^{3}$ sporangia $\mathrm{ml}^{-1}$ at the center of each tuber slice.

The inoculated tuber slices were incubated at $16 \pm 0.5^{\circ} \mathrm{C}$ with $12 \mathrm{hr}$ light cycle. Percent area of tuber slice colonized by P. infestans was estimated by visual observation on the 6th day. The experiment was repeated within 15 days under similar laboratory conditions. For both the assays, the inoculums was prepared as described by. ${ }^{18}$

\section{Data analysis}

The area under disease progress curve is used to summarize the progress of disease severity. The area under the disease progress curve was estimated using the following formula. ${ }^{19}$

$$
\begin{aligned}
& \text { AUDPC }=\sum_{i=1}^{n-1}(Y i+1+Y i) 0.5(T i+1-T i) \\
& \text { Where }
\end{aligned}
$$

$\mathrm{Y}_{\mathrm{i}}=$ late blight disease severity $\%$ on the ith date

$\mathrm{T} \mathrm{i}=$ date on which the disease was scored

$\mathrm{n}=$ numbers of dates on which disease was scored

To standardize the quantification of resistance for different assays and field experiment, $0-9$ scale value, ${ }^{20,21}$ was used based on data taken for measuring resistance in several ways. Here, ascending numbers represent increasing susceptibility.

$$
\text { standard scale }(0-9)=\frac{\text { Severity of test plant }}{\text { Severity of control }} \times 9.0
$$

Where 'severity' was the AUDPC for the field experiment, mean lesion size $\left(\mathrm{cm}^{2}\right)$ for the detached leaf assay and percent area covered by colony for the tuber slice assay. For detached leaf and tuber slice assays, the average of two repeated experiments was used. The data recorded during the study were processed to fit into $\mathrm{R}$ studio software for analysis, Microsoft excel program was used for data tabulation, and Duncan's multiple range test (DMRT) was carried out at $5 \%$ and $1 \%$ level of significance. The data entry was done to develop ANOVA Table 1. Correlation and regression analysis were done for group comparison and to test the main and interaction effects.

\section{Results and discussion}

\section{Field response of potato cultivars to late blight}

Late blight symptoms first appeared on 19 September, 2016, i.e. 30 days after planting (DAP) on plants of susceptible variety Kufri Jyoti followed by Kalo (32 DAP), Rato, Hale, Seto, Lumle Seto, Janakdev, Phul and Lumle Kalo (Table 1). Kufri Jyoti followed by Kalo was significantly different for disease appearance from the remaining cultivars, which were at par from each other. Significantly highest disease severity was found on 58 DAP for susceptible variety Kufri Jyoti $(100 \%)$ followed by Phul $(65.56 \%)$, Seto $(55.56 \%)$, and Lumle Seto $(51.11 \%)$. Lumle Kalo had significantly lowest severity (32.22\%) which was at par with Janakdev (37.78\%) (Table 1). The results showed that Kufri Jyoti was found highly susceptible (HS) to late blight while Phul was susceptible (S). Hale, Rato, Lumle Seto, Seto and Kalo were found moderately resistant (MR) to late blight while Janakdev and Lumle Kalo were resistant (R) under Pakhribas conditions.

Table I Days to appearance of late blight (LB) after planting (DAP), maximum disease severity and field response of potato cultivars to the disease during September 2016 to January 2017 at Pakhribas, Dhankuta

\begin{tabular}{llll}
\hline LB appearance & & $\begin{array}{l}\text { Maximum disease } \\
\text { severity }\end{array}$ & Field \\
\hline Variety & DAP & $\mathbf{( 5 8} \mathbf{D A P})$ & $\mathbf{( 0 - 9}$ scale) \\
\hline Seto & $35.33^{\mathrm{a}}$ & $55.56^{\mathrm{c}}$ & $4.83 \mathrm{MR}$ \\
Kalo & $32.33^{\mathrm{b}}$ & $48.89^{\mathrm{cd}}$ & $4.78 \mathrm{MR}$ \\
Rato & $35^{\mathrm{a}}$ & $47.78^{\mathrm{cd}}$ & $4.50 \mathrm{MR}$ \\
Phul & $35.67^{\mathrm{a}}$ & $65.56^{\mathrm{b}}$ & $6.00 \mathrm{~S}$ \\
Hale & $35^{\mathrm{a}}$ & $43.33 \mathrm{~d}^{\mathrm{e}}$ & $3.89 \mathrm{MR}$ \\
Lumle Seto & $35.33^{\mathrm{a}}$ & $51.11 \mathrm{~cd}$ & $4.61 \mathrm{MR}$ \\
Lumle Kalo & $35.67^{\mathrm{a}}$ & $32.22^{\mathrm{f}}$ & $3.00 \mathrm{R}$ \\
Kufri Jyoti & $30.33^{\mathrm{c}}$ & $100^{\mathrm{a}}$ & $9.00 \mathrm{HS}$ \\
Janakdev & $35.33^{\mathrm{a}}$ & $37.78^{\mathrm{ef}}$ & $3.44 \mathrm{R}$ \\
\hline F-test & $<.001$ & $<.001$ & $<.001$ \\
LSD & 0.84 & 8.21 & 0.68 \\
CV & 1.41 & 8.85 & 8.07 \\
SEm & 0.24 & 22.48 & 0.16 \\
\hline
\end{tabular}


Value with the same letters in a column is not significantly different at $1 \%$ by DMRT Area under disease progress curve (AUDPC) of each test cultivar is shown in Figure 1. The AUDPC value was less for Lumle Kalo and Janakdev compared to other cultivars (Kufri Jyoti, Phul, Kalo and Seto) indicating their higher level of resistance in these cultivars. In the beginning, the increment of disease on all cultivars was slower (till 2nd November), however, afterwards the disease increment on varieties Kufri Jyoti and Phul was highly fast followed by Kalo, Seto, Lumle Seto, Rato and Hale; but slower in Janakdev and Lumle Kalo. The faster increament of the disease in the susceptible varieties might be due to increased relative humidity $(64.43 \%-72.86 \%)$ and decreased temperature $\left(22.63^{\circ} \mathrm{C}-\right.$ $21.17^{\circ} \mathrm{C}$ ) after 2 nd day of November. It indicates that they have got more susceptible genes compared to other cultivars. Due to different genetic background of potato cultivars and prevailing environmental conditions, differential rate of disease development may have been recorded in different cultivars. Host resistance in detached leaf and tuber slice assays Different potato cultivars tested by detached leaf and tuber slice assays showed different reactions to late blight Table 2. In detached leaf assay, cultivar Janakdev showed highly resistant reaction while it showed moderately resistant reaction in tuber slice assay. Cultivar Kalo showed resistance in both the detached leaf and tuber slice assays while it along with Lumle Kalo, Phul and Rato also gave same reactions in tuber slice assay. In tuber slice assay, cultivar Seto showed moderately resistant reaction while Lumle Kalo and Hale showed same reactions in detached leaf assay. Similarly in detached leaf assay, Lumle Seto, Rato, Seto and Phul showed susceptible reactions to late blight while Hale and Lumle Seto showed the same reactions in tuber slice assay. Kufri Jyoti showed highly susceptible reaction in both the assays Table 2 . Value with the same letters in a column is not significantly different at $1 \%$ by DMRT the results showed that foliage resistance may not express in the tuber or vice versa as resistance in leaves and tubers may be governed by different genetic systems and/or reflect structural differences in the tissues. Three major components are known to contribute to late blight resistance in tubers; 1) a physical barrier consisting of several layers of phloem cells, known the periderm; 2 ) the outer cortical cell layers that retard the growth of lesions and can completely block hyphal growth; and 3) medulla storage tissues which can reduce hyphal growth and sporulation of $P$. infestans. ${ }^{21-23}$ Furthermore, immature tubers are more susceptible to tuber blight than mature tubers. ${ }^{24}$ In our experiment also mature tested potato tubers were used for tuber slice assay. These might be the reasons why most of the cultivars, which showed tuber resistance, could not express resistance in detached leaf assay.

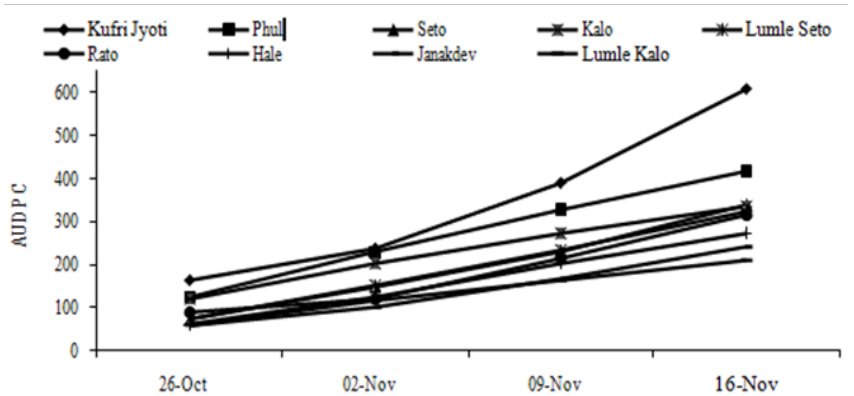

Figure I AUDPC value of late blight on different potato cultivars during October to November 2016 at Pakhribas, Dhankuta.
Table 2 Reaction of potato cultivars to P. infestans isolates in 0-9 scale in detached leaf and tuber slice assays

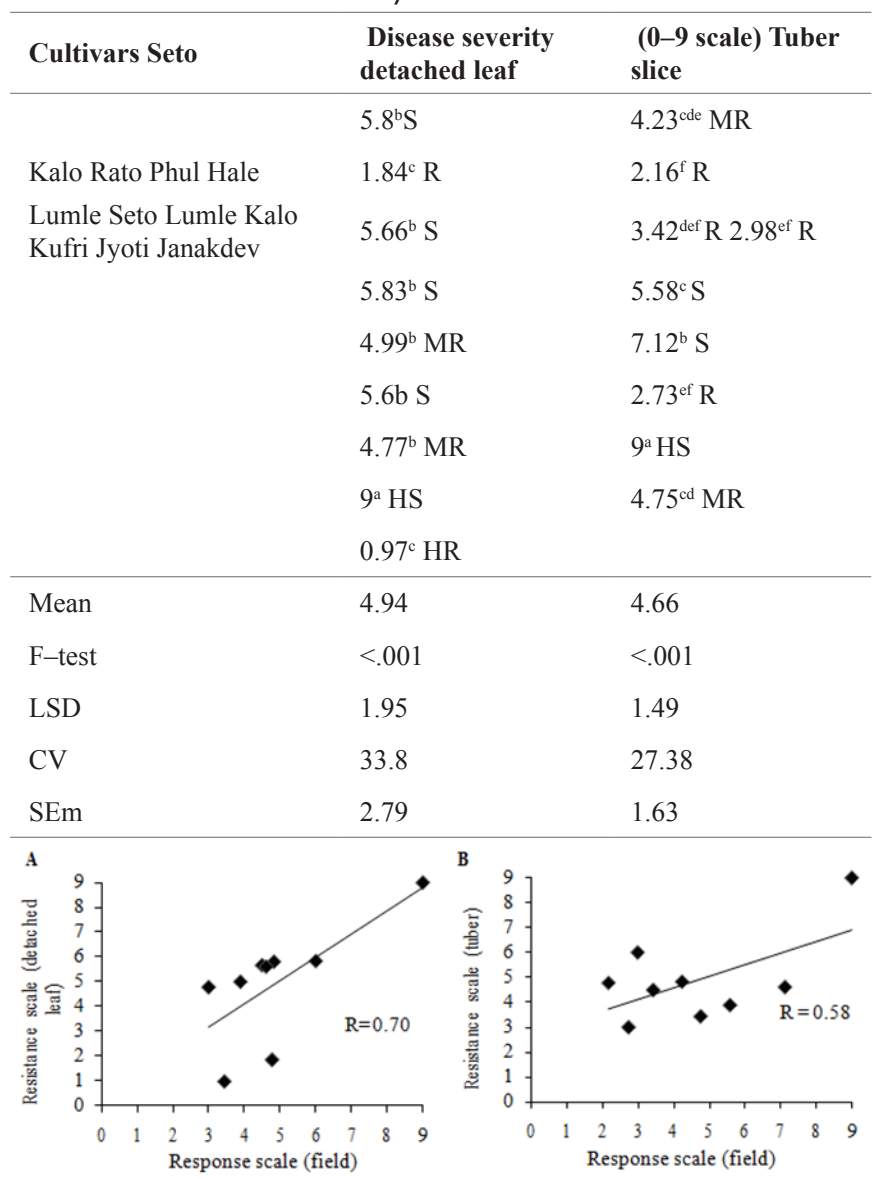

Figure 2 Correlation of field response with detached leaf $[\mathrm{A}]$ and tuber slice [B] assays.

\section{Correlations of field response with detached leaf and tuber slice assays}

The correlation between the field response and detached leaf assay was high $(\mathrm{r}=0.70)$. This could be due to the fact that in both the field and detached leaf assays leaves were used for disease assessment. The field response and tuber slice assays were positively correlated, but the relationship was poor $(r=0.58)$. This could be attributed to the use of different plant parts for the assays..$^{25}$ also found similar results with field experiments under artificially inoculated conditions but in our study the field experiment was conducted under natural epiphytotic conditions. The lower correlation values are primarily an indication of the degree to which high levels of resistance in assays was not detected in the field and this should be taken into consideration. The reasons of inconsistency between field values and those from the other assays under control conditions are not known. But our results seem to be consistent with others, ${ }^{26}$ who claimed that laboratory assays cannot replace the value of evaluating germplasm for foliar resistance to late blight under field conditions.

\section{Conclusion}

In the present study cultivars Lumle Kalo and Janakdev showed higher level of resistance in both field and laboratory experiments. 
Thus, Lumle Kalo can be utilized as source of resistance for breeding and recommended for general cultivation by farmers in Pakhribas and similar conditions.

\section{Acknowledgments}

Authors are thankful to National Agricultural Research and Development Fund (NARDF) for providing fund for the research.

\section{Conflicts of interest}

The author declares there is no conflicts of interest.

\section{References}

1. Hardy B, Trognitz B, Forbes G. Late blight breeding at CIP: Progress to date. CIP Circular. 1995

2. CIP. Enhancing the global late blight network. Global initiative on late blight. Centro International de la Papa. 1996.

3. Fry WE, Goodwin SB. Re-emergence of potato and tomato late blight in the United States. Plant Disease. 1997;81(12):1349-1357.

4. Haverkort AJ, Struik PC, Visser RG, et al. Applied biotechnology to combat late blight in potato caused by Phytophthora infestans. Potato Research. 2009;52(3):249-264.

5. Shrestha SK. Study on late blight disease of potato in Nepal. Nepal J Agric. 1976;11(6): 91-105.

6. Shrestha SK, Shrestha K, Kobayashi K, et al. First report of A1 and A2 mating types of Phytophthora infestans on potato and tomato in Nepal. Plant Disease. 1998;82(9):1064-1064.

7. Shrestha SK. Late blight of potato: Its magnitude distribution losses and approaches to management in Nepal. In African Potato Association Conference Proceedings. 2000;5(1):303-307.

8. Dhital BK, Ghimire SR. Blighted potato. In The Rising Nepal. 1996.

9. Sharma BP, KC H. Participatory IDM research on potato late blight through farmers' field school. Advances of Horticultural Research in Nepal. In: Proceedings of the Fourth National Workshop on Horticulture. Horticulture Research Division. 2004;1(1):205-210.

10. Singh D. Fungicidal spray schedule for economical management of potato late blight in North-western hills of India. Indian Journal of Mycology and Plant Pathology. 1996;26(3):252-255.

11. Inglis DA, Johnson DA, Legard DE, et al. Relative resistances of potato clones in response to new and old populations of Phytophthora infestans. Plant Disease. 1996;80(5):574-578.

12. Cotes JM, Nustez CE, Martinez R, et al. Analyzing genotype by environment interaction in potato using yield-stability index. American Journal of Potato Research. 2002;79(3):211-218.
13. Dorrance AE, Inglis DA. Assessment of greenhouse and laboratory screening methods for evaluating potato foliage for resistance to late blight. Plant Disease. 1997;81(10):1206-1213.

14. Platt HWB, Tai G. Relationship between resistance to late blight in potato foliage and tubers of cultivars and breeding selections with different resistance levels. American Journal of Potato Research. 1998;75(4):173-178.

15. Kirk WW, Felcher KJ, Douches DS, et al. Effect of host plant resistance and reduced rates and frequencies of fungicide application to control potato late blight. Plant Disease. 2001;85(10):1113-1118.

16. Black W. The nature and inheritance of field resistance to late blight (Phytophthora infestans) in potatoes. American Potato Journal. 1970;47(8):279-288.

17. Nilsson BA. Component analysis of general resistance to Phytophthora infestans in clones from the Colombian potato collection. Potato Research. 1981;24(3):239-244.

18. Sharma BP, Manandhar HK, Forbes GA, et al. Efficacy of fungicides against Phytophthora infestans in potato under laboratory and field conditions. Nepal Agriculture Research Journal. 2011;11(1):28-39.

19. Campbell CL, Madden LV. Introduction to plant disease epidemiology. John Wiley \& Sons. 1990.

20. Yuen JE, Forbes GA. Estimating the level of susceptibility to Phytophthora infestans in potato genotypes. Phytopathology. 2009;99(6):782-786.

21. Pathak N, Clarke DD. Studies on the resistance of the outer cortical tissues of the tubers of some potato cultivars to Phytophthora infestans. Physiological and molecular plant pathology. 1987;31(1):123-132.

22. Flier WG, Turkensteen LJ, Mulder A. Variation in tuber pathogenicity of Phytophthora infestans in the Netherlands. Potato Research. 1998;41(4):345-354.

23. Flier WG, Turkensteen LJ, Van Den Bosch, et al. Differential interaction of Phytophthora infestans on tubers of potato cultivars with different levels of blight resistance. Plant Pathology. 2001;50(3):292-301.

24. Grinberger M, Kadish D, Cohen Y. Infectivity of metalaxyl-sensitive and-resistant isolates of Phytophthora infestans to whole potato tubers as affected by tuber aging and storage. Phytoparasitica. 1995; 23(2):165-175.

25. Sharma BP, Forbes GA, Manandhar HK, et al. Determination of resistance to Phytophthora infestans on potato plants in field, laboratory and greenhouse conditions. Journal of Agricultural Science. 2013;5(5):148-148.

26. Douches DS, Kirk WW, Bertram MA, et al. Foliar and tuber assessment of late blight (Phytophthora infestans (Mont.) de Bary) reaction in cultivated potato (Solanumtuberosum L.). Potato Research. 2002;45(2):215-224. 